\title{
PENDIDIKAN ANAK USIA DINI MENURUT PSIKOLOGI ISLAMI
}

\author{
BAHRIL HIDAYAT ${ }^{1}$, ARY ANTONY PUTRA ${ }^{2}$, MUSADDAD HARAHAP ${ }^{3}$ \\ ${ }^{1 \&}$ Prodi Pendidikan Islam Anak Usia Dini(PIAUD) \\ ${ }^{3}$ Pendidikan Agama Islam (PAI)
}

Fakultas Agama Islam (FAI) Universitas Islam Riau (UIR)

bahrilhidayat@fis.uir.ac.id

\begin{abstract}
The relationship among early childhood education is related to the Islamic Education and Islamic Psychology perspective. Discussion of this article forms of theoretical review and expected to generate scientific reference to formulate explanation and development of science about Islamic Early Childhood Education according to Islamic Psychology. Islamic Education into early childhood as students, not only based on the principles of western Educational Psychology and Psychology of Learning (Psychology Learning and Teaching) from the Western scientist theory, but must be based on Islamic values and concept too. By applying the concept, the internalization of Islamic Education into the psychophysiological of early childhood will be achieved. According to the integration of principles of science and Islam through 5 Strategic Development of Islamic Education for Early Childhood Based on Islamic Psychology Principles, namely, 1) awakening learners' self-awareness about Islam, 2) involves the educational environment in to the learning activities, 3) understanding the child's age development by the method of playing, 4) using techniques that appeal to early childhood, 5) directing the child to develop their unique potential.
\end{abstract}

Keywords: Islamic Education, Islamic Psychology, Educational Psychology, Psychology Learning and Teaching

\section{PENDAHULUAN}

Pendidikan Islam tentang kajian dan pengembangan anak usia dini, dikenal rumpun keilmuan Pendidikan Islam Anak Usia Dini. Pendidikan Islam Anak Usia Dini merupakan upaya disiplin ilmu untuk membentuk calon-calon pendidik mengetahui, memahami, dan menerapkan nilai-nilai pendidikan
Islam terhadap anak usia dini dan lingkungan pendidikan, baik dalam pendidikan formal, maupun pendidikan non-formal. Dalam proses pendidikan anak usia dini, diperlukan pendekatan keislaman dan perilaku yang berhubungan dengan Psikologi Islami yang bertolak dari Psikologi Agama. Berbagai kajian penelitian dan 
pemikiran keilmuan dan keislaman bisa dijadikan rujukan pengembangan rumpun ilmu pendidikan anak usia dini (Hidayat, B., 2017). Berkaitan dengan pandangan tersebut, untuk membentuk pendidikan anak usia dini yang berkualitas, harus dimulai dari pemahaman yang utuh tentang perilaku manusia, khususnya perilaku pendidik, peserta didik, perilaku sosial ekonomis, maupun tahapan perkembangan manusia.

Disiplin ilmu yang berisikan tentang kajian tentang perilaku manusia dikenal dengan Psikologi. Secara umum, psikologi bermakna ilmu tentang perilaku organisme, penyelidikan tentang gejala-gejala kejiwaan manusia, dan ilmu tentang perilaku manusia (Hidayat, B., 2014). Sementara itu, teori-teori Barat yang dijadikan rujukan keilmuan dalam psikologi memiliki kelemahan memahami manusia secara utuh karena kecenderungan psikologi barat yang memisahkan diri dari agama. Kelemahan tersebut berimplikasi kepada hambatan untuk memahami dan mencarikan jalan keluar atau solusi permasalahan manusia, khususnya individuindividu yang menjalankan ketaatan beragama dan berhasil mencapai pembentukan perilaku yang baik (Ancok, D., Suroso, F. N., \& Ardani, M. S., 2000). Oleh karena itu, kajian Psikologi Islami menjadi penyempurnaan rumusan pemahaman tentang gejala perilaku dan kejiwaan manusia sekaligus merumuskan jalan keluar dari dinamika permasalahan manusia, baik perilaku manusia dalam proses dan fase perkembangan, ekonomi, organisasi, kesehatan, khususnya proses pendidikan.

Permasalahan dalam dunia pendidikan dan pendidikan Islam, berkaitan dengan rujukan teori-teori psikologi pendidikan dan psikologi belajar yang berasal dari psikologi Barat. Rujukan teoretis tersebut seringkali tidak sesuai dengan implementasi pendidikan Islam, khususnya pendidikan anak usia dini menurut perspektif Islam karena psikologi Barat tidak memberikan perhatian yang besar kepada agama, khususnya Islam. Kondisi tersebut mengakibatkan pengembangan pendidikan Islam pada anak usia dini membutuhkan Psikologi Islami sebagai rujukan teoretis yang relevan dengan perumusan, pengembangan, dan penemuan-penemuan keilmuan yang integratif antara Islam dan Pendidikan. Harapannya pendekatan keilmuan dan keislaman berjalan secara dinamis ke dalam jiwa peserta didik, pendidik, dan lingkungan pendidikan Islam, khususnya dimensi pendidikan Islam anak usia dini.

Definisi modern pendidikan bermakna proses penyadaran yang terjadi karena interaksi berbagai faktor yang menyangkut manusia dan potensinya serta alam lingkungan, serta dalam proses 
penyadaran tersebut, individu akan menemukan potensi jati dirinya dan alam lingkungan, baik kelebihan dan kelemahannya (Mulyadi, S., Basuki, H., \& Rahardjo, W., 2016). Definisi pendidikan tersebut memiliki orientasi makna pada adanya suatu proses yang melibatkan interaksi antara berbagai faktor di dalam manusia. Proses interaksi dilakukan untuk menemukan jati diri dan potensi individu dan lingkungan. Kemudian individu bisa berkembang sesuai dengan potensi masingmasing dengan melibatkan alam lingkungan sebagai instrumen pengembangan potensi diri tersebut.

Pendidikan Islam memiliki tujuan yang jelas dalam membentuk perilaku yang mulia dan kepribadian luhur berdasarkan nilai-nilai keislaman, khususnya pengembangan potensi manusia. Dasar filosofis pendidikan Islam terletak pada pembentukan pendidik dan peserta didik yang memberikan dampak perubahan perilaku dan kepribadian berdasarkan sumbersumber hukum Islam dan keilmuan terdahulu dan kontemporer. Berdasarkan dasar filosofis dan pengembangan metodologis kependidikan Islam akan diperoleh rumusan keilmuan dan keislaman yang aplikatif sesuai nilai-nilai keislaman dan keilmuan untuk mencapai tujuan pendidikan dan implikasi pendidikan terhadap hakikat manusia.
Implikasi Islam tentang hakikat manusia dalam hubungannya dengan pendidikan Islam, mencakup, 1) sistem pendidikan Islam seharusnya dibangun dengan pola integrasi antara pendidikan qalbiyah dan aqliyah, 2) pendidikan Islam mengembangkan potensi yang dimiliki manusia secara maksimal, 3) pendidikan Islam harus dijadikan sarana yang kondusif bagi proses transformasi ilmu pengetahuan dan budaya Islami dari satu generasi kepada generasi berikutnya, 4) konsep hakikat manusia dan fungsi penciptaannya dirumuskan berdasarkan melalui pendekatan kewahyuan, empirik keilmuan, dan rasional filosofis, 5) proses internalisasi nilai-nilai Islam dilaksanakan melalui peran aktif individu maupun orang lain, misalnya guru atau pendidik (Syarif, M., 2017). Lima implikasi hakikat manusia dan pendidikan Islam tersebut merupakan hubungan mendasar antara pembentukan perilaku lingkungan pendidikan (misalnya, pendidik dan peserta didik) yang mengimplementasikan keislaman

dan keilmuan secara integratif.

Pendidikan Islam harus mampu mengembangkan potensi hati (qolbiyah) dan potensi otak (aqliyah) agar berhasil mengembangkan potensi individu sesuai dengan kaidah-kaidah psikologi Islam, baik adari aspek filosofis maupun praktis berdasarkan sumber hukum Islam 
(Mujib, A., 2017). Dengan peningkatan potensi individu tersebut, langkah regenerasi keilmuan dan keislaman berdasarkan hakikat manusia menurut wahyu (alQur'an) dan sumber keilmuan akan menginternalisasi atau tertanam ke dalam jiwa lingkungan pendidikan. Setelah proses internalisasi tersebut berjalan dengan baik, kajian, diskusi, penelitian, maupun penyebaran keilmuan dan keislaman dalam dinamika keilmuan (transformasi dan transfer wawasan pengetahuan) akan berbanding lurus dengan pembentukan kepribadian pendidik dan peserta didik. Dinamika implikasi pendidikan Islam tersebut merupakan konsep mendasar memahami mekanisme dan hakikat pendidikan Islam dalam tataran perspektif Psikologi Islami.

$$
\text { Psikologi Islami yang }
$$

memiliki tujuan menjadi salah satu mazhab psikologi kontemporer menghasilkan pemikiran dan penelitian yang komprehensif tentang dinamika hakikat perilaku manusia yang mulia (insan kamil) berdasarkan sumber keislaman dan keilmuan (Lubis, B. H., \& Nashori, F., 2002). Psikologi Islami melakukan pengembangan pemikiran dan penelitian ilmiah tentang berbagai variabel, misalnya tahapan atau fase perkembangan manusia, proses pembelajaran dan dinamika masalah perundungan di sekolah (Nashori, F., Mayasari, G., Dewisukma, G., Iskandar, D.,
Wicaksono, K., Prehastamto, C., Andriansyah, Y., 2017), fungsi perilaku sabar dan kelapang-dadaan. Lebih jauh lagi, penelitian studi ekonomi keislaman dalam psikologi manajemen dalam dunia industri dan organisasi (Rusby, Z., Arifin, K., Zakaria, S. Z. S., \& Razman, M. R., 2016), menunjukkan motivasi yang tinggi dari ilmuwan muslim untuk menemukan integrasi disiplin ilmu perilaku dan manajemen dunia kerja kontemporer.

Sementara itu, referensi psikologi pendidikan yang dicontohkan Nabi Muhammad SAW. dalam mendidik para sahabat terus diteliti oleh ilmuwan muslim kontemporer. Referensi psikologi Islami tersebut menjadi rujukan keilmuan psikologi kontemporer sebagai landasan ilmiah untuk membantu pendidikan Islam melakukan pengembangan dinamika keilmuan kependidikan. Jadi, untuk memahami pendidikan Islam, khususnya pendidikan Islam Anak Usia Dini, antara Psikologi Islami dan Pendidikan Islam merupakan dua rumpun ilmu yang memiliki daya sanding kajian ilmiah yang signifikan sebagai rujukan dunia pendidikan dan pengajaran yang diamanahkan kepada umat manusia.

Dalam Al-Qur'an, Allah swt. menjelaskan tentang menyampaikan amanah ilmu kepada orang lain sebagai landasan (hukum) pengambilan keputusan yang tepat untuk mencarikan jalan keluar dari 
GENERASI EMAS

Jurnal Pendidikan Islam Anak Usia Dini

Volume 1 NO. 1, 2018 problematika kehidupan dan pendidikan. Al-Qur' an surah AnNisa ayat 58, Allah SWT berfirman sebagai berikut.

Sesungguhnya $r$ Allah
menyuruh $\quad$ kamu
menyampaikan $\quad$ amanat
kepada yang $\quad$ berhak
menerimanya, dan (menyuruh
kamu) apabila menetapkan
hukum di antara manusia
supaya kamu menetapkan
dengan adil.Sesungguhnya
Allah memberi pengajaran
yang sebaik-baiknya
kepadamu.Sesungguhnya
Allah adalah Maha
Mendengar lagi Maha
Melihat.(QS. 4:58)

Ayat tersebut merupakan landasan keislaman tentang penetapan hukum keilmuan yang adil dengan menyampaikan amanah keilmuan kepada orang yang tepat tentang hakikat ilmu (ontologis), dengan cara atau metode yang tepat (epistemologis), dan akhirnya memiliki nilai-nilai keadilan yang bermanfaat (aksiologis) kepada pengguna ilmu. Dengan melakukan pengajaran yang terbaik menurut kaidah keislaman dan filsafat ilmu, Allah SWT mencontohkan akhlak ilahiah melalui pengajaran yang terbaik dari Al-Qur'an dan ilmuwan muslim wajib meneladani hal itu agar Allah menyaksikan dengan asma Maha Mendengar dan Maha
Melihat-Nya proses pengajaran yang bernilai kepada umat manusia.

Proses pengajaran keilmuan erat kaitannya dengan upaya peningkatan wawasan keilmuan kependidikan dan keislaman, mulai dari mempelajari fase perkembangan manusia dari usia dini sampai usia lanjut, dinamika bersosialisasi, maupun interaksi pengajaran dan pendidikan yang berlangsung dalam proses kependidikan tersebut. Pendidik anak usia dini memberikan materi pembelajaran yang tepat berdasarkan fase perkembangan anak, melibatkan lingkungan pendidikan anak, misalnnya orang tua peserta didik di dalam proses dan aktivitas pendidikan. Bentuk kegiatan pengajaran yang relevan bisa berupa pengenalan ibadah shalat dan haji, maupun pengenalan baca tulis Al-Qur' an berdasarkan metodemetode tertentu (Alucyana, 2017). Oleh karena itu, pendidik harus meningkatkan wawasan keilmuan mereka secara berkala dan kontinu untuk meningkatkan kualitas mengajar dan mendidik di lembaga pendidikan Islam, baik secara formal maupun non-formal.

Selain itu, pendidik atau guru harus mengenalkan anak-anak usia dini agar memahami konsep dasar perilaku ekonomis dalam sehari-hari, misalnya jual beli, bersedekah, membayar zakat (Hamzah, H., Rusby, Z., \& Hamzah, Z., 2013). Dengan mengenalkan konsep dasar ekonomi Islam sejak usia dini, anak- 
anak akan membentuk perilaku filantropis atau kedermawanan sejak masa awal perkembangan fisik dan mental mereka. Pembentukan perilaku filantropis tersebut akan membentuk kesiapan anak-anak untuk memasuki fase perkembangan selanjutnya memasuki jenjang pendidikan yang lebih tinggi dan berhasil mengembangkan potensi mereka yang unik.

\section{PEMBAHASAN}

Fokus pembahasan tulisan ini memaparkan hubungan pendidikan anak usia dini dari perspektif pendidikan Islam dan psikologi Islami. Pembahasan berbentuk analisis teori (theoretical review) yang relevan dengan tema tulisan diharapkan menghasilkan pemikiran keilmuan untuk merumuskan penjelasan dan pengembangan keilmuan tentang pendidikan anak usia dini menurut Psikologi Islami. Rumusan-rumusan analisis teori diharapkan menjadi landasan pengembangan pemikiran dan penelitian lebih lanjut oleh penulis dan peneliti lain untuk memahami kebutuhan pendidikan anak usia dini berdasarkan prinsip-prinsip pendidikan Islam dan Psikologi Islami yang memiliki kesamaan tujuan dalam membentuk perilaku, kepribadian, dan pengembangan potensi semua unsur yang terlibat di dalam lingkungan pendidikan, khususnya potensi anak usia dini dalam pendidikan Islam.
Pendidikan Islam pada anak usia dini tidak bisa berdasarkan pada prinsip-prinsip teori psikologi pendidikan dan psikologi belajar dari Barat, akan tetapi harus berdasarkan pada nilai-nilai keislaman. Pendidikan keilmuan dan keislaman yang ditanamkan kepada anak usia dini secara aplikatif akan mencapai kualitas pribadi insan kamil yang diajarkan Islam maupun pengembangan potensi peserta didik dan lingkungan pendidikan melalui jati diri anak yang unik dan berkembang secara gradual menurut fase perkembangan mereka. Dengan mengaplikasikan hal itu, internalisasi pendidikan Islam ke dalam psikofisiologis anak usia dini akan tercapai sesuai kaidah-kaidah keilmuan dan keislaman yang integratif.

Berdasarkan teori-teori di atas, perlu dirumuskan langkahlangkah strategis pengembangan pendidikan anak usia dini. Pengembangan pendidikan itu berdasarkan dasar pandangan psikologi islami dalam membentuk pendidikan Islam yang memiliki ciri khas pengembangan potensi berdasarkan prinsip-prinsip psikologi pendidikan, psikologi belajar, manajemen dan perilaku ekonomis, maupun pengembangan pendidikan keislaman lainnya. Dalam hal ini, langkah strategis tersebut diberi namapengembangan strategis pendidikan islam anak usia dini berdasarkan prinsip psikologi is lami. 


$$
\text { Pengembangan strategis }
$$

Pendidikan Islam Anak Usia Dini berdasarkan prinsip Psikologi Islami tersebut dapat diaplikasikan setidaknya ke dalam bentuk aktivitas proses pengajaran dan pendidikan sebagai berikut.

\section{Menumbuhkan kesadaran peserta didik tentang Islam}

Pendidik atau guru di lingkungan pendidikan anak usia dini seharusnya menumbuhkan kesadaran anak tentang Islam melalui aktivitas bermain dan belajar. Kesadaran anak ditingkatkan melalui pengetahuan mendasar tentang nilai tauhid dan ketuhanan (aqidah) dalam keseharian dan peribadatan anak sehingga membentuk selfawareness (kesadaran diri) yang tertanam sejak usia dini pada peserta didik. Pembentukan kebiasaan berdoa, menjaga ibadah shalat, atau pengenalan konsep dasar umrah dan haji akan meningkatkan kesadaran anak tentang Islam. Lebih jauh lagi, pengenalan konsep dasar jual beli, sedekah, zakat, dapat diaplikasikan melalui teknik pasar murah yang diperankan oleh anak usia dini dalam bentuk teknik Role Play agar anak-anak memperoleh kesadaran perilaku ekonomis keislaman yang berhubungan dengan aspek filantropis berdasarkan keislaman.
2. Melibatkan pendidikan dalam aktivitas
belajar Anak usia dini seharusnya diajarkan agar bersosialisasi dengan baik, demikian pula lingkungan pendidikan yang tersedia di sekitar anak-anak. Orang tua anak merupakan faktor penentu pencapaian keberhasilan pendidikan anak usia dini menurut Psikologi Islami. Pendidik atau guru sebaiknya secara intensif melibatkan peran dan fungsi orang tua di sekolah maupun di rumah agar orang tua terlibat secara partisipatif dalam kegiatan bermain dan belajar anak. Selain lingkungan pendidikan orang tua, pihak pemangku kepentingan lain, misalnya dinas pendidikan, komisi perlindungan anak, dan stakeholder lain dalam ruang lingkup lingkungan pendidikan anak, seharusnya dilibatkan dalam pengembangan metode, peran serta, dan aktivitas belajar dan bermain anak usia dini.

\section{Memahami perkembangan usia} anak dengan metode bermain

Dunia anak memiliki keunikan. Proses pembelajaran mereka harus berhasil menciptakan suasana yang menyenangkan. Dalam hal ini, bermain merupakan aktivitas belajar yang tepat bagi anak usia dini. Oleh karena itu, metode bermain dalam belajar merupakan cara dan teknik yang efektif dalam pendidikan anak usia dini. 


\begin{abstract}
Berbagai metode yang menggunakan pendekatan seni, cenderung efektif untuk meningkatkan nuansa bermain pada ruang belajar anak-anak, baik di dalam ruangan tertutup (in-door) maupun kelas-kelas di ruangan terbuka (out-door).
\end{abstract}

\section{Menggunakan teknik-teknik} yang menarik perhatian anak usia dini

Pendidik atau guru sebaiknya mampu menggunakan teknik bermain dan belajar yang menarik perhatian anak usia dini. Dalam prinsip psikologi belajar dan psikologi pendidikan, fungsi afeksi, kognisi, dan psikomotorik anak melibatkan aspek asosiasi, persepsi, memori, sampai kepada proses membentuk motivasi belajar peserta didik. Pendidik bisa membentuk motivasi anak usia dini melalui teknik berkisah (Tambak, S., 2016) dan memasukkan kisah-kisah Islami yang bersumber dari Al-Qur'an dan Hadis sebagai tema teknik berkisah yang digunakan guru. Kisah-kisah pendidikan dan keislaman tersebut akan menarik perhatian anak-anak apabila guru menyajikan paparan cerita dengan ekspresif, intonasi yang jelas, dan menggunakan alat peraga yang memadai. Selain itu, penggunaan Alat Permainan Edukatif (APE) bisa dijadikan instrumen pembelajaran untuk mengenal konsep dasar baca tulis Al-Qur'an, maupun pengembangan potensi afeksi anak melalui bermain secara berkelompok, bereksperimen dengan APE untuk meningkatkan potensi kognisi, dan memberikan ruang gerak yang leluasa untuk meningkatkan potensi psikomotorik anak.

\section{Mengarahkan anak}

\section{mengembangkan}

potensi mereka yang unik

Anak usia dini sangat unik dengan potensi masing-masing yang berbeda. Teori Multiple Intelligence atau Kecerdasan Majemuk menunjukkan potensi kecerdasan individu tidak terletak pada satu bidang saja, akan tetapi tergantung kepada minat dan bakat anak yang berbeda (unik). Pendidik harus mampu mengenali potensi peserta didik dan mengembangkan potensi tersebut agar anak-anak menemukan jati diri dengan cara melibatkan berbagai instrumen yang tersedia. Berbagai instrumen multimedia, audio, audio visual, mampu menjadi instrumen pembelajaran bagi guru untuk meningkatkan kualitas mengajar dan mendidik (Zulkifli, Z., 2018). Setelah itu, anak-anak akan berkembang sesuai arah potensi mereka yang unik pada fase perkembangan selanjutnya berdasarkan jenjang pendidikan yang mereka lalui secara bertahap.

Lima langkah pengembangan strategis pendidikan islam anak usia 
dini berdasarkan prinsip psikologi islami di atas merupakan manifestasi dari Al-Qur'an surah an-Nisa ayat 58, berkaitan dengan perintah Allah SWT. untuk mengajarkan nilai pendidikan keislaman dengan cara yang baik kepada peserta didik. Aplikasi lima langkah itu akan meningkatkan potensi anak-anak sebagai individu dalam melanjutkan regenerasi keilmuan dan keislaman berdasarkan hakikat manusia menurut wahyu (Al-Qur'an) dan sumber keilmuan. Setelah itu, anak usia dini akan menginternalisasikan atau menanamkan nilai keilmuan dan keislaman ke dalam jiwa mereka dan lingkungan.

Setelah proses internalisasi tersebut berjalan, kajian, diskusi, penelitian, maupun penyebaran keilmuan dan keislaman pada dinamika keilmuan (transformasi dan transfer wawasan pengetahuan) akan membentuk kepribadian pendidik dan peserta didik yang berkualitas. Dinamika implikasi pendidikan Islam melalui lima langkah pengembangan strategis pendidikan islam anak usia dini berdasarkan prinsip psikologi islami merupakan konsep mendasar memahami dan menerapkan mekanisme dan hakikat pendidikan Islam dalam tataran perspektif Psikologi Islami kepada anak usia dini.

\section{PENUTUP}

Teori-teori Barat yang dijadikan rujukan keilmuan dalam psikologi memiliki kelemahan memahami manusia secara utuh karena kecenderungan psikologi Barat yang memisahkan diri dari agama. Kelemahan tersebut berimplikasi kepada hambatan untuk memahami dan mencarikan jalan keluar atau solusi permasalahan manusia, khususnya dalam pendidikan Islam dan pengembangan potensi anak usia dini berdasarkan nilai keilmuan dan keislaman. Kajian Psikologi Islami menjadi penyempurnaan rumusan pemahaman tentang gejala perilaku dan kejiwaan manusia yang terlibat dalam proses pendidikan karena rujukan Psikologi Islami bersumber kepada Al-Qur'an dan Hadist. Dengan mengembalikan fungsi AlQur'an dan Hadist, serta sumber hukum Islam lainnya ke dalam dasardasar psikologi pendidikan dan psikologi belajar pada rumpun pendidikan Islam anak usia dini, maka tujuan dan hakikat pendidikan pada anak akan tercapai, yaitu pembentukan kesadaran diri dan kepribadian yang luhur berdasarkan jati diri dan potensi anak sebagai peserta didik sesuai ajaran kependidikan Islam.

\section{DAFTAR PUSTAKA}

Al-Qur' an dan Terjemahan.

Alucyana, A. 2017. Pembelajaran Al-Quran Untuk Anak Usia Dini dengan Metode Muyassar. In 2nd Annual Conference on 
Islamic Early Childhood Education 2017.

Ancok, D., Suroso, F. N., \& Ardani, M. S. (2000). Psikologi islami: Solusi islam atas problemproblem psikologi. Pustaka Pelajar.

Hamzah, H., Rusby, Z., \& Hamzah, Z. (2013).Analysis problem of Baitul Maal Wat Tamwil (BMT) in Pekanbaru. Lambert Academic Publishing (LAP)

Hidayat, B. (2017). Pembelajaran AlQur' an pada anak usia dini menurut psikologi agama dan neurosains. 2nd Annual International Conference on Islamic Early Childhood Education 2017. Yogyakarta: UIN Sunan Kalijaga.

Lubis, B. H., \& Nashori, F. (2002).Dialektika Psikologi dan Pandangan Islam. Unri Press.

Mujib, A. (2017). Pengembangan Fitrah Peserta Didik dalam Pendidikan Islam. EDUKASI: Jurnal Penelitian Pendidikan Agama dan Keagamaan, Vol. 1 No. 3.
Mujib, A. (2017). Pengembangan Kecerdasan Qalbiyah Dalam Pendidikan Islam. EDUKASI: Jurnal Penelitian Pendidikan Agama dan Keagamaan, Vol. 1 No.1.

Nashori, F., Mayasari, G., Dewisukma, G., Iskandar, D., Wicaksono, K., Prehastamto, C., Andriansyah, Y. (2017). The Model of bullying behavior on senior high school students: a case study in Indonesia. Psychology and Education Journal. 54 (1-2): 65-75.

Syarif, M. (2017).Pelaksanaan pendidikan karakter dalam pembelajaran PAI di SMK Hasanah Pekanbaru.AlThariqah: Jurnal Pendidikan Agama Islam, Vol. 1No. 1, 2740.

Tambak, S. (2016).Metode bercerita dalam pembelajaran pendidikan agama Islam.Al-Thariqah: Jurnal Pendidikan Agama Islam, Vol. 1No. 1, 1-26. 